\title{
Prostitution in Lagos: a sociomedical study
}

\author{
U. G. OLERU
}

From the Department of Community Health, College of Medicine, University of Lagos

SUMMARY A study of 150 hotel prostitutes in Lagos was undertaken to determine their socioeconomic identity and, through an assessment of their health knowledge, attitude, and practice, their probable impact on public health. The subjects were selected from 15 hotels, representing $20 \%$ of the estimated hotel universe in Lagos and different socioeconomic strata. Information was obtained from the subjects with the help of the hotel staff, who arranged pre-interview conferences with them. Prostitution in Lagos is not organised and there are no figures on the prostitute population. Ninety-eight per cent of the women in the study population were aged between 15 and 44 and $70 \%$ of them had children. Forty per cent were married and $24 \%$ were either divorced or separated. The most important reason given for prostitution was unhappiness in the home $(50 \%)$ but the undercurrent of poverty, especially in a low-income society, is undoubtedly a major motive. More than half $(55 \cdot 3 \%)$ of the subjects selected their clients and the most important criteria for selection were physical fitness and ability to pay. Physical fitness was defined as the absence of signs of gonorrhea. The women's level of education was a significant factor in selection of clients and in mode of health care. More than $60 \%$ of those who selected their clients had had some education or had completed secondary schooling. Thirty-three per cent of those who did not select their clients had had no education at all and $45 \%$ had received primary education only. The attitude of the subjects to health care suggests an opportunity for the control of disease among prostitutes if prostitution is organised.

Social and legal attitudes to prostitution vary greatly between countries. In a few countries where prostitution has been legalised, simultaneous attempts have been made to eliminate the threat to public health. In these countries, the production of records of periodic medical examination has been made a licensing requirement. ${ }^{1}$

In Nigeria prostitution is regarded as a social evil, but rapid urbanisation of Nigerian communities and the strains this has imposed on traditional family structures $^{2}$ have helped to reduce hostility to it. In Nigerian cities, especially in Lagos, prostitution is of the street and hotel type. Prostitutes are not registered so their numbers are not precisely known.

The objective of this study was to determine the socioeconomic identity of prostitutes in Lagos, and their probable impact on public health, through an assessment of their health knowledge, attitude and practice.

\section{Materials and Methods}

Fifteen hotels were randomly selected from a list ob 50. There is no accurate register of hote establishments in Lagos and the sample size probably accounts for $20 \%$ of the hotel universe in the city. The ${ }^{+}$ breakdown of the hotels according to the socioeconomic status of their patrons is shown in Table 1.

The hotel staff provided the investigating team with an estimate of the number of prostitutes who ply each hotel. The estimated population of prostitutes in 15 hotels where interviews were conducted was 295 . One hundred and fifty subjects were included in the study.

All interviews were conducted in rooms provided by the hotel staff. The interview team consisted of three workers who were dressed in the medical outfits of a doctor, a nurse, and a laboratory

Table 1 Hotels by socioeconomic category, number of subjects, and estimated population of prostitutes in study sample

\begin{tabular}{|c|c|c|c|c|c|}
\hline \multicolumn{3}{|l|}{ HOTELS } & \multicolumn{2}{|c|}{ SUBJECTS } & \multirow{2}{*}{$\begin{array}{l}\text { ESTIMATED } \\
\text { POPULATION OF } \\
\text { PROSTITUTES }\end{array}$} \\
\hline Category & No. & $\%$ & No. & $\%$ & \\
\hline High income, international grade & 3 & 20 & 34 & 22.67 & 50 \\
\hline $\begin{array}{l}\text { Middle income, limited international } \\
\text { patronage }\end{array}$ & 5 & $33 \cdot 33$ & 56 & $37 \cdot 33$ & 90 \\
\hline Middle to low income & 7 & $46 \cdot 66$ & 60 & $40 \cdot 00$ & 155 \\
\hline TOTAL & 15 & 99.99 & 150 & 100.00 & 295 \\
\hline
\end{tabular}


technician, so as to emphasise to the subjects that the interviewers were not a law enforcement team. Subjects were invited into the room one at a time to eliminate peer influence.

A questionnaire was administered to each of the 150 subjects to elicit information on age, marital status, family history, gravidity, parity, educational background, motives for prostitution, health care, symptoms of sexually transmitted diseases, drug use, and housing.

\section{Results}

MARRIAGE, FAMILY, AND PROSTITUTION

Table 2 shows the marital status of the subjects. Sixty-one $(\mathbf{4 0} \cdot \mathbf{7 \%})$ were currently married and over $70 \%$ had been married at some time.

Table 2 Marital status of subjects

\begin{tabular}{lcc}
\hline & No. & $\%$ \\
\hline Married & 61 & $40 \cdot 7$ \\
Single & 40 & $26 \cdot 7$ \\
Separated & 24 & $16 \cdot 0$ \\
Divorced & 12 & $8 \cdot 0$ \\
Widowed & 13 & $8 \cdot 6$ \\
TOTAL & 150 & $100 \cdot 00$ \\
\hline
\end{tabular}

The age distribution of the subjects indicated that $147(98 \%)$ were between 15 and 44 , the active reproductive years. Only 12 of the 147 were aged between 15 and 19.

Forty-one $(27 \cdot 3 \%)$ were childless; $70(46 \cdot 7 \%)$ had one to three children and $34(22 \cdot 7 \%)$ had four to six children. In all, 109 subjects had to raise families in addition to practising prostitution and 63 of these $(57 \cdot 8 \%)$ had their children living with them.

Table 3 shows the association between marital status and the motive given for prostitution. It seems that the association is significent $\left(\chi_{2}=34.83\right.$; $P<0.001$ ). For women with a living spouse (that is, married, separated or divorced), the most important reason given for adopting prostitution was desertion, unhappiness in the home, or a broken home. Among the widowed subjects, poverty $(30.77 \%)$ and unhappy homes $(33.4 \%)$ were stated to be the most important reasons. Among single women, the most important reason given for prostitution was sexual pleasure. The Nigerian civil war, 1966-70, did not have a significant impact on the choice of prostitution by the subjects.

\section{EDUCATION, HEALTH, AND PROSTITUTION}

Table 4 shows the association between the level of education and the motive for prostitution. With the exception of the 34 women with no formal education, the proportion of individuals reporting an unhappy home as the motive for prostitution decreased as the level of education increased. This suggests that a higher level of education may have offered subjects from unhappy homes better options for making a living than prostitution.

Table 5 shows the association between educational level and choice of client. Among the 83 subjects who selected their clients this association was statistically significant $(P<0 \cdot 01)$. The criteria for selection were both physical fitness and ability to pay, ability to pay

Table 3 Association between marital status and motives for prostitution

\begin{tabular}{|c|c|c|c|c|c|c|c|c|c|c|}
\hline $\begin{array}{l}\text { MARITAL } \\
\text { STATUS }\end{array}$ & $\begin{array}{l}\text { POVERTY } \\
\text { No. }\end{array}$ & $\%$ & $\begin{array}{l}\text { UNH } \\
\text { DES } \\
\text { BRO } \\
\text { No. }\end{array}$ & $\begin{array}{l}\text { HOME, } \\
N, \\
\text { IOME } \\
\%\end{array}$ & $\begin{array}{l}S E X \\
P L E \\
\text { No. }\end{array}$ & $\%$ & $\begin{array}{l}\text { CIVIL } \\
\text { WAR } \\
\text { No. }\end{array}$ & $\%$ & $\begin{array}{l}\text { TOTAL } \\
\text { No. }\end{array}$ & $\%$ \\
\hline $\begin{array}{l}\text { Single } \\
\text { Married } \\
\text { Separated } \\
\text { Divorced } \\
\text { Widowed }\end{array}$ & $\begin{array}{r}4 \\
12 \\
5 \\
3 \\
4\end{array}$ & $\begin{array}{l}10 \\
19 \cdot 67 \\
20 \cdot 83 \\
25 \cdot 0 \\
30 \cdot 77\end{array}$ & $\begin{array}{r}11 \\
33 \\
18 \\
8 \\
5\end{array}$ & $\begin{array}{l}27 \cdot 5 \\
54 \cdot 10 \\
75 \cdot 0 \\
66 \cdot 66 \\
38 \cdot 46\end{array}$ & $\begin{array}{l}19 \\
13 \\
- \\
-1\end{array}$ & $\begin{array}{l}47 \cdot 5 \\
21 \cdot 31 \\
- \\
- \\
7 \cdot 69\end{array}$ & $\begin{array}{l}6 \\
3 \\
1 \\
1 \\
3\end{array}$ & $\begin{array}{r}15 \\
4 \cdot 92 \\
4 \cdot 17 \\
8 \cdot 33 \\
23 \cdot 08\end{array}$ & $\begin{array}{l}40 \\
61 \\
24 \\
12 \\
13\end{array}$ & $\begin{array}{l}100 \\
100 \\
100 \\
100 \\
100\end{array}$ \\
\hline TOTAL & 28 & $18 \cdot 77$ & 75 & 50.00 & 33 & 22.00 & 14 & $9 \cdot 33$ & 150 & 1000 \\
\hline
\end{tabular}

$\chi^{2}=34.83 \quad P<0.001$

Table 4 Association between level of education and motives for prostitution

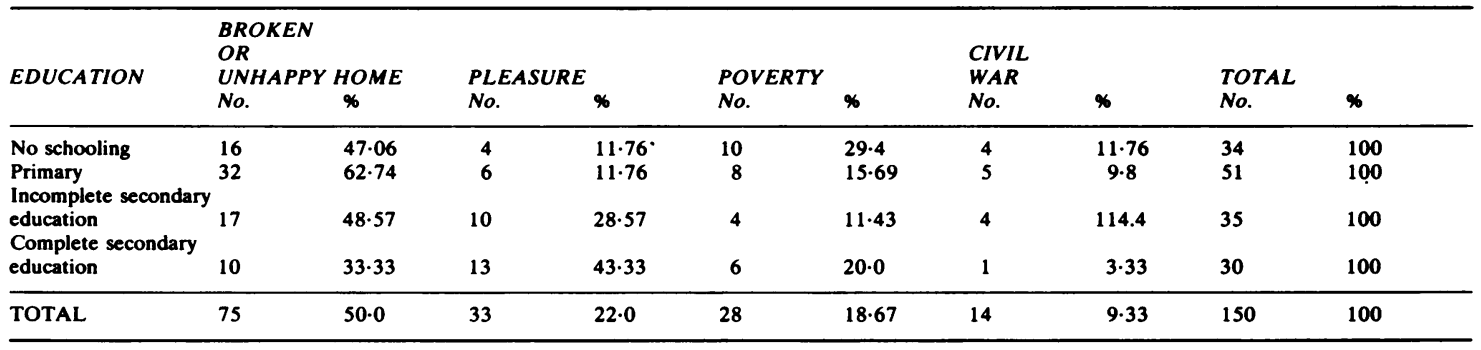

$x^{2}=17.68 \quad P<0.05$ 
Table 5 Association between level of education and selection of patrons

\begin{tabular}{|c|c|c|c|c|c|c|c|c|}
\hline EDUCATION & \multicolumn{2}{|c|}{$\begin{array}{l}\text { PHYSICAL FITNESS } \\
\text { AND } \\
\text { ABILITY TO PAY }\end{array}$} & \multicolumn{2}{|c|}{$\begin{array}{l}\text { PHYSICAL } \\
\text { FITNESS ALONE }\end{array}$} & \multicolumn{2}{|c|}{$\begin{array}{l}\text { ABILITY TO } \\
P A Y A L O N E\end{array}$} & \multicolumn{2}{|c|}{ TOTAL } \\
\hline $\begin{array}{l}\text { No schooling } \\
\text { Primary } \\
\text { Incomplete secondary education } \\
\text { Complete secondary education }\end{array}$ & $\begin{array}{r}2 \\
6 \\
17 \\
14\end{array}$ & $\begin{array}{l}22 \cdot 22 \\
25 \cdot 9 \\
58 \cdot 62 \\
66 \cdot 66\end{array}$ & $\begin{array}{l}2 \\
5 \\
5 \\
3\end{array}$ & $\begin{array}{l}22 \cdot 22 \\
20 \cdot 83 \\
17 \cdot 24 \\
19 \cdot 05\end{array}$ & $\begin{array}{r}5 \\
13 \\
7 \\
4\end{array}$ & $\begin{array}{l}55 \cdot 56 \\
54 \cdot 16 \\
24 \cdot 14 \\
19 \cdot 05\end{array}$ & $\begin{array}{r}9 \\
24 \\
29 \\
21\end{array}$ & $\begin{array}{l}100 \\
100 \\
100 \\
100\end{array}$ \\
\hline TOTAL & 39 & 46.99 & 15 & 18.07 & 29 & $34 \cdot 94$ & 83 & 100 \\
\hline
\end{tabular}

$x^{2}=19.44 \quad P<0.01$

Table 6 Association between level of education and selection of health care

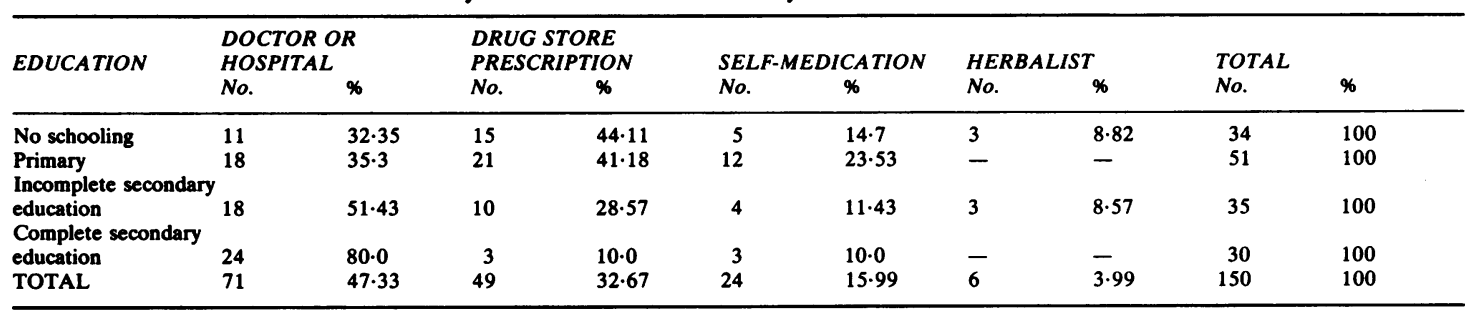

$x^{2}=26.90 \quad P<0.005$

alone, and physical fitness alone. Physical fitness was defined as absence of signs of venereal disease, especially gonorrhea, as evidenced by the urethra. Thirty-nine $(47 \%)$ of the women took into account both the physical fitness of their clients and their ability to pay. Among those who did not choose their clients, $22(32 \cdot 83 \%)$ had had no formal education at all, $30(44.78 \%)$ had had primary education only, eight $(11.94 \%)$ did not complete secondary education, and seven $(10.45 \%)$ did.

Only $35(52.22 \%)$ of those who did not select their clients could positively identify the signs of gonorrhea in a man.

Table 6 shows the relationship between education and approach to health care. This association was statistically significant $(P<0.005)$. Nearly half of the subjects $(47 \%)$ chose to visit the hospital or doctor's clinic, but women who had completed their secondary education were more likely to do this than less well-educated women. This relationship between selection of hospital or clinic care and level of education probably holds true for the general population, although there are no available data to support this assumption.

The next most important choice of health care was a visit to the chemist or drug store. The latter are sometimes manned by trained pharmacists but more often by untrained personnel whose prescription of particular drugs is as likely to be influenced by the availability of those drugs in the store as by their customers' complaints.
Table 7 Conditions for which subjects had self-medication or medication prescribed by a doctor in the six months before the study

\begin{tabular}{lcc}
\hline CONDITION & No. & $\%$ \\
\hline Vaginal itching and discharge & 62 & 41.33 \\
Vaginal discharge and joint pain & 40 & 26.67 \\
Skin diseases & 30 & 20.00 \\
Sores & 6 & 4.00 \\
Cough & 12 & 8.00 \\
\hline TOTAL & 150 & 100.00 \\
\hline
\end{tabular}

FREQUENCY OF DISEASE

All the subjects stated that in the six months before the study they had treated themselves for an illness. Seventy-two subjects $(48 \%)$ said they had treated themselves only once, and 56 subjects $(37 \cdot 3 \%)$ said they had treated themselves twice; the rest had treated themselves more frequently.

Table 7 shows their conditions. It is evident that at least about two-thirds of these were venereal. This conclusion is suggested by the fact that $61(40 \cdot 7 \%)$ had taken antibiotics, 46 Panadol, 29 (19.33\%) had used vaginal pessaries, and $16(10 \cdot 66 \%)$ had used skin cream.

DRUG USE, SMOKING, AND PROSTITUTION

The average daily income of the subjects ranged between $N 2400$ and $N 4000$. At the time of the survey $\mathrm{N} 1.00$ was equivalent to $\$ 1 \cdot 70$. This income is substantially higher than average; only $30 \%$ of the Nigerian population earn more than $\mathrm{N} 1000$ a year (Shobanjo 1979, personal communication). 
None of the women were dependent on drugs before becoming prostitutes. However, the use of non-addictive drugs developed among them in the course of prostitution and their substantial income provided them with the means to support the habit. One hundred and twenty-one of the subjects $(80.7 \%)$ admitted to taking drugs. Of these, $32(26.4 \%)$ took them to be more relaxed or to sleep, $25(20.7 \%)$ took them to keep awake, and 16(13.2\%) to be 'high'. The preparations used included Valium, amphetamines, and several containing ephedrine. These suit the demands of prostitution-be alert and active when there are clients, sleep when business is slow. No subject admitted to using 'hard' drugs.

\section{Discussion}

In a study in Denver and Philadelphia, Weissman and File ${ }^{3}$ observed a tendency for women who were drug addicts to turn to prostitution and other crimes to support their drug habit. The women in this study had no history of serious crimes and opted for prostitution on the grounds of unhappiness in the home $(50 \%)$ and poverty $(18 \cdot 67 \%)$. Although only $18.7 \%$ of the subjects specifically identified poverty as the main reason for prostitution, poverty probably had a lot to do with the decision to become a prostitute. The use of drugs differed from that described by Weissman and File. ${ }^{3}$ The subjects took drugs acting on the central nervous system, dependence-producing drugs to satisfy the dictates of prostitution to be awake or to sleep when necessary.

Although 54 (36\%) of the women refused to accept clients whom they suspected of having venereal disease, more than 100 admitted to having suffered signs and symptoms of sexually transmitted conditions at least once in the six months before the study.

Only $71(66 \cdot 7 \%)$ of the women sought health care from doctors or hospitals and this choice was significantly influenced by the level of education. Regular medical examination could be introduced as a means of controlling these diseases.

The family history of the subjects indicated that a large proportion (69.4\%) had children to care for. Some of these children lived with the subjects and others with relatives, especially grandmothers. The psychological impact of prostitution on the children of the subject is the topic of another study.

We thank the managements of the hotels where the study was conducted and also Mr. P. Alabunge of the Data Processing Unit of the Department of Community Health for technical assistance.

Reprints from Dr. O. G. Oleru, Department of Community Health, College of Medicine, University of Lagos, Private Mail Bag 12003, Lagos, Nigeria.

\section{References}

${ }^{1}$ Borelli S. Problems of prostitution. Mater Med Nord 1969; 10: 489-501.

${ }^{2}$ Mabogunje AL. Urbanisation in Nigeria. London: University of London Press, 1968.

${ }^{3}$ Weissman JC, File KN. Criminal behaviour patterns of female addicts: a comparison of findings in two cities. Int J Addict 1976; 16: 1063-75. 